\title{
Have You, My Little Serpents, a New Skin? Transforming English Studies and the Scholarship of Teaching and Learning
}

\author{
Lee Easton \& Kelly Hewson
}

Mount Royal University

King and Knight (2010) argue that English Studies' instructors must "articulate and develop their tacit assumptions [about English teaching] and create a discipline-grounded idiom for pedagogical research and reflection" (p. 323). We suggest that the scholarship of teaching and learning (SoTL) invites English educators to reflect more deeply about the assumptions upon which our favoured methodologies are based. At the same time, SoTL's often uncritical reliance on students' umarked voices for many of its insights troubles us. We suggest that while the scholarship of teaching and learning can provide the necessary structure for systematic reflection about English Studies pedagogies, SoTL would benefit from a more substantial engagement with what English Studies calls theory. In so doing, SoTL can add another critical question to its agenda: "For whom do these practices work?"

Change? Yes, we must change, only show me the Theory, and I will be at the barricades, show me the book of the next Beautiful Theory, and I promise you these blind eyes will see again.... Show me the words that will reorder the world, or else keep silent. If the snake sheds his skin before a new skin is ready, naked he will be in the world, prey to the forces of chaos. Without his skin, he will be dismantled, lose coherence and die. Have you, my little serpents, a new skin?

- Oldest Living Bolshevik in the World from Tony Kushner's Angels in America, Part Two: Perestroika

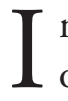

n a variety of venues in 2007-8, we called upon our disciplinary colleagues to embark on a transformation of English Studies to respond to the major shifts - social, technological, cultural - we believed had placed us out of step with the students we regularly taught. Our claim - a manifesto, 
actually - was based on the premise that English Studies needed to engage with the affective turn if it were to re-forge for a new millennium a discipline structured by the social practices, shared generational experiences, works of art and literature of the previous century (Easton \& Hewson, 2007a). We realized, of course, that such transformation could not occur without learning from the Theory Wars of the $80 \mathrm{~s}$ and 90s, but we also knew that that it would be equally foolish to base a transformative impulse on a single totalizing theoretical concept towards which the Oldest Living Bolshevik gestures. At the time, we advocated a pedagogy which would take more fully into account the proposition that deep learning is not solely a cognitive affair - that it involves the emotional and bodily dimensions theorists of affect were busily investigating (and most educators have long known). We exhorted our discipline, among other things, to resurrect out-of-favour progenitors of English such as F.R. Leavis who intuited that reading literature was as much about feeling as it was about the skill of close reading (Easton \& Hewson, 2008). Our calls for English Studies to reorder itself unregarded, the discipline remains essentially unchanged. Assimilating through its dominant pedagogical, methodological practices new and potentially disruptive objects of study, English Studies has not so much transformed as adapted itself to the "structures of feeling" of the early $21^{\text {st }}$ century (Williams, 1977, p.132), themselves in flux from the spate of global movements insisting on reform.

The image the Oldest Bolshevik evoked in our epigraph - of a snake shedding an old skin and acquiring a new one - galvanizes us. What is it we must shed and what is it we must acquire if our pedagogies are to be coherent, compelling, and alive to the times in which we live today? Attempts to answer this question have made us draw closer to our students as we have explored their interpretive strategies, knowledges, and resistances (Easton \& Hewson 2008, 2010).

Based on these forays, we concur with Nicole King and Ben Knight's (2011) assertion that English Studies' pedagogues need to do "more than the exchange of tips, methods, and 'good practice,' important though they are. Teachers...need to articulate and develop their tacit assumptions [about English teaching] and create a discipline-grounded idiom for pedagogical research and reflection (p. 323). When we came into contact with the Scholarship of Teaching and Learning (SoTL), primarily through the work of colleagues who had been through our home institution's scholars' programme, we took note of its substantial body of research addressing some of the very questions we had been raising. There is much to be learned, we discovered, through a dialogue between English Studies and SoTL, and our paper outlines some of the ways in which each can enrich the other.

\section{Sustaining the Pedagogical}

Peter Medway (2010) and David Stevens (2011), in a recent exchange in Changing English, reflect on the philosophical underpinnings of English pedagogy as part of the Enlightenment project of education. Such high-level reflections, useful and generative as they may be, are insufficient to produce the transformed English Studies curriculum we envision: in our view, a re-invigorated curriculum requires a sustained engagement with the scholarship of teaching and learning. With its systematic focus on the "evidence about what (if any) cognitive or affective effect that a method ha[s] on [students'] learning" (Dewar, 2008, p.18), SoTL promotes precisely the kind of rigorous pedagogical research and consideration King and Knight advocate. Such research will remind those of us in English Studies that our focus on textual interpretation and production has often been at the expense of remembering the discipline's historical roots: roots that have not been so much about subject matter - literature - as about how English has relied on a specific kind of pedagogical milieu in which distinctive ethical and aesthetic capacities are inculcated to produce a particular kind of citizen (Hunter, 1994). Working from its claim as the discipline best suited to produce (print) literacy, English - from F.R. Leavis to Raymond Williams to bell hooks - has been shaped by its commitment to a social mission. A connection to SoTL reminds English Studies' practitioners, particularly when we get mired in a tangle of theoretical intricacies, to 
rededicate ourselves to pedagogy: our origins, after all, are in teaching and education. Indeed, Peter Medway (2011) argues that "to find its proper direction English needs to start from an idea of education before an idea of the subject" (p. 10).

Moreover, the scholarship of teaching and learning invites English teachers to reflect more deeply about the assumptions upon which our usual methodologies - close reading, reader responses and essay assignments - are based. Such engagement will help English Studies articulate more clearly its threshold concepts in both the cognitive and affective domains. Taking up SoTL - initiated concepts will lead English teachers to explore the bottlenecks that occur in their curriculum. Through this exploration we imagine that we might finally have an answer to the enduring question: What on earth happens in an "English" class?

Interestingly, our own engagement with SoTL shifted our pedagogical gaze away from what we think students should or ought to do in the English classroom and re-oriented us to what students actually do. Our SoTL work in film studies, for instance, revealed to us our over-reliance on teacherly readings of films and directed our ears to a more attentive listening to, and learning from, the surprising, sophisticated and sometimes distressingly banal interpretations our students produce. This was a powerful transformative move for us and our pedagogy, as the focus shifted from a reproduction of "expert" readings (and all the enlightening elements assumed to be contained therein) in favour of understanding the context of students' choices and interpretations so that we could start from where they were, not where we imagined or presumed them to be. Our encounters with SoTL taught us that as English transforms itself, the skins first shed are those of the teacher. Whether we like or not, we must move away from the security of transmission pedagogy. After all, the only learning about teaching many of us in English Studies received was via mimesis, or, more likely, osmosis.

\section{Insisting on the Critical}

Shaped by English Studies' turn to theory in the later $20^{\text {th }}$ century, our initial encounters with SoTL and its methodologies led us to wonder about the implications of the discipline's often uncritical reliance on students' unmarked voices for many of its insights. While inspired by the efforts at many institutions to engage students as participants and coresearchers in SoTL, we note that the student-as-dataprovider rarely appears in her or his gendered, aged, and, if ever, racialised or classed form. The emphasis on the monolithic voice of the generic student is also a recurring motif in SoTL research. For example, student response journals are a key resource for SoTL investigators to determine authentic student experience in the classroom and/or to encourage students' coming into voice. However valuable such investigations are, we think it's important for SoTL to heed the feminist, postcolonial and queer theories addressing what Goodall (2000) refers to as the "partial, partisan and [hence] problematic" nature of voice (p.55) in writing pedagogies, and to a lesser extent, the classroom. Those feminist pedagogies envisioned by Adrienne Rich and Audre Lorde that caution us that voice isn't always about sharing that voice can be silent, and this doesn't necessarily mean a lack of intention or agency or power - will help enrich the kinds of insights the scholarship of teaching and learning provides. And as important as it is to help students develop theirs, voices are never simply the products of a pedagogical interaction nor are they more likely to be real when produced in a classroom - a space, as much as we'd like to try to build it as such, that cannot always be truly safe or egalitarian.

SoTL's attending to the intricacies of classroom practice and its relationships to student learning brings to the fore much of what remains unexamined among many of us in positions of power and responsibility in those very classrooms. In fact, most SoTL practitioners will attest to how their teaching strategies are under constant revision in order to best respond to the general demands of the subject and its various students. Shedding what doesn't work and taking on what has been verified to work, they are in transformation. While SoTL is refreshingly multi-perspectival with its focus dually directed at student learning and scholarly teaching, 
we worry about its narrowness of vision regarding the social locations in which knowledges are produced. Perhaps this narrowness results from the questions that SoTL has so far pursued. Hutchings (2007) contends that SoTL has developed a tentative taxonomy of three questions: "What is?" "What works?" and "What could be?" A preoccupation with the first two questions has led SoTL to value interpretive, descriptive work with an instrumentalist goal of improving student performance, often avoiding the troublesome nature of identities that we ourselves find so central to thinking about teaching and student learning.

Fortunately, Hutchings' third question "What could be?" - offers an opportunity for us to address our concerns. For example, what approaches to teaching and learning could avoid both the voyeuristic relation that emerges when we - teachers - read the personal stories of students, use them in our research, and disseminate findings based on them to build our careers and the instrumentalist perspective that SoTL currently promotes when students' voices are used unproblematically to inform more effective teaching strategies? Our tentative answer adds a fourth question to Hutchings' taxonomy: "For whom does this practice and pedagogy work?" We believe answering this question will produce SoTL research more attendant to our complicities as instructors and scholars in structures that may perpetuate inequality and more critically informed by the particular institutional, political or pedagogical contexts out of which students are asked to voice their views. Such research will, we contend, induce English Studies to acquire a new skin.

\section{Biography}

Dewar, J. (2008). An apology for the scholarship of teaching and learning. InSight: A Journal for Scholarly Teaching, 3(1), 17-22.

Easton, L. \& Hewson, K. (2007a). The possibility of new possibilities? Teaching for affect. Delivered at the International Association for Commonwealth Literature and Language
Studies, Vancouver, British Columbia.

Easton, L. \& Hewson, K. (2007b). Notes towards a teaching manifesto for the $21^{\text {st }}$ century. Keynote Address delivered at Thompson Rivers University Graduate Education Symposium, Kamloops, British Columbia.

Easton, L. \& Hewson, K. (2008). Cosmopolitanism and student spectators in the film studies classroom. Delivered at Mount Royal University's Using Film to Teach: A Multidisciplinary Forum, Calgary, Alberta.

Easton, L. \& Hewson, K. (2010). Reading monsters: Reflections on the interplay of race, whiteness and Canadian identity in a film studies classroom. Reception: Texts, Readers, Audiences, History, 2(1), 116-148.

Goodall, H.L. (2000). Writing the new ethnography. Lanham, MA: Altamira Press.

Hutchings, P. (2000). Approaching the scholarship of teaching and learning. In P. Hutchings, (Ed.), Opening Lines: Approaches to the scholarship of teaching and learning (pp. 1-10). Menlo Park, CA: The Carnegie Foundation for the Advancement of Teaching.

Hunter, I. (1994). History lessons for 'English.' Cultural Studies, 8(1), 142-162.

King, N. \& Knight, B. (2010). Guest editors' introduction. Pedagogy 7(3), 323-333.

Kushner, T. (1992). Angels in America, part two: Perestroika. New York: Theatre Communications Groups, Inc.

Medway, P. (2010). English and enlightenment. Changing English, 17(1), 3-12.

Stevens, D. (2011). Critically enlightened romantic values and English pedagogy: A response to Peter Medway. Changing English, 18(1), 45-56. 
Williams, R. (1977). Marxism and literature. Oxford:

Oxford University Press.

\section{Biographies}

Lee Easton and Kelly Hewson enjoy a rich teaching and writing partnership from which they have produced work on intersections of the postcolonial and the queer (Ariel); Cross-Dressing (upcoming in Caribbean Sexualities, UVirginia Press); reading representations of race in American film (reception); students spectators and the Canadian nation (in playing with memories; essays on Guy Maddin, UManitoba Press); the US-Canada Border and the Canadian Student Film Spectator (upcoming in theUS-Canada Border Network, WLU press); Notes Towards a Teaching Manifesto (Keynote Address: TRU Graduate Education symposium); theories of affect and transformative pedagogies; and most recently, Resiliency Thinking. Lee Easton will be Associate Dean, School of Communication and Literary Studies, Sheridan College as of August 2012 while Kelly Hewson, Associate Professor, continues her film, postcolonial, and SoTL studies' work at Mount Royal University. 